\begin{tabular}{|c|c|c|c|c|c|c|c|c|}
\hline \multicolumn{9}{|c|}{-Technical note- } \\
\hline 魏 & 秀 & 復 & 高＼cjkstart橋 & & 淳 & 金 & 本 & 幸 秀 \\
\hline 國 & 信 & 啓 & 松 林 & 景 & 子 & 風 & 本 & 新一郎 \\
\hline 光 & 太 & 郎 & & & & & & \\
\hline
\end{tabular}

\title{
Transverse Laminotomy
}

by

Hidefuku Gi, M.D., Jun Takahashi, M.D., Yukihide Kanemoto, M.D., Nobuhiro Mikuni, M.D., Keiko Matsubayashi, M.D., Shinichiro Okamoto, M.D., and Taro Fukumitsu, M.D.

from

Department of Neurosurgery, Osaka Red Cross Hospital

Several reported laminoplasties made no mention of yellow ligament biomechanical reconstruction as one of the important posterior sustaining elements in cervical surgery. Transverse laminotomy, coined by the present authors, is successfully done by microneurosurgical technique traversing the mid-half of the lamina and spinous process by $1.5 \mathrm{~mm}$ ball bar drilling. This procedure causes no injury to the yellow ligament, since it adheres tightly to the lower half and the next upper third of the back of the laminae. When the traversed lamina and spinous process are re-fused in a simple manner and other laminae are reconstructed by Koyama's method of laminoplasty, the biomechanism of yellow ligament can be spared in the longitudinal direction.

This is the first paper indicating the method of sparing the biomechanism of yellow ligament even after laminotomy. And neurosurgeons, who have well mastered microsurgical techniques, can prepare the necessary minimum operative fields for intra-spinal canal procedures.

(Received June 2, 1992 ; accepted February 16, 1993)

Key words : transverse laminotomy, yellow ligament

$$
\text { Jpn J Neurosurg (Tokyo) } 2: 260-262,1993
$$

\section{はじめに}

頸椎椎弓切除術は, 術後の biomechanical な不安定性 のために常に頸椎の変形に注意を要した。この欠点を予 防すべく本邦において開発された種々の頸椎管拡大術 ${ }^{3)}$ は, 頸椎の後方支持組織のうち椎弓や棘突起の bone component の再構築をうまく工夫し発達した術式であ る。しかしながら後方支持組織の一つである黄色靯带の 観点からは, 従来の方法では部分的な解剖学的な温存は
図れても，機能的な再構築は成されていなかった。

本稿において，われうれは椎弓を中央で横切（transverse laminotomy）し，再び骨癒合することによって黄 色䩲帯の垂直方向の機能温存を図る方法をKoyama's laminoplasty with transverse laminotomy (modified Koyama’s method）として報告する。またこの方法に よって, 椎管内操作が必要な時の椎弓切開範囲を必要最 小限度にすることが可能でもある。

大阪赤十字病院脳神経外科〔連絡先：魏 秀復， $\bar{\top} 551$ 大阪市大正区北村 $3-4-5$ 大阪府済生会泉尾病院脳神経外科〕

Address reprint requests to: Hidefuku Gi, M.D. Department of Neurosurgery, Osakafu Saiseikai Izuo Hospital, Kitamura 3-4-5,

Taisho-ku, 551 Osaka, Japan 


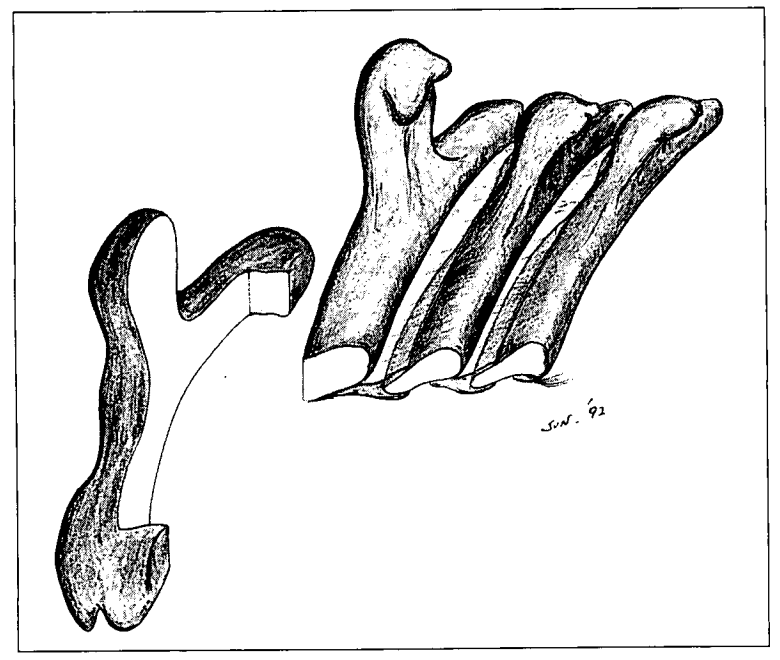

Fig. 1 Method of transverse laminotomy (C2)

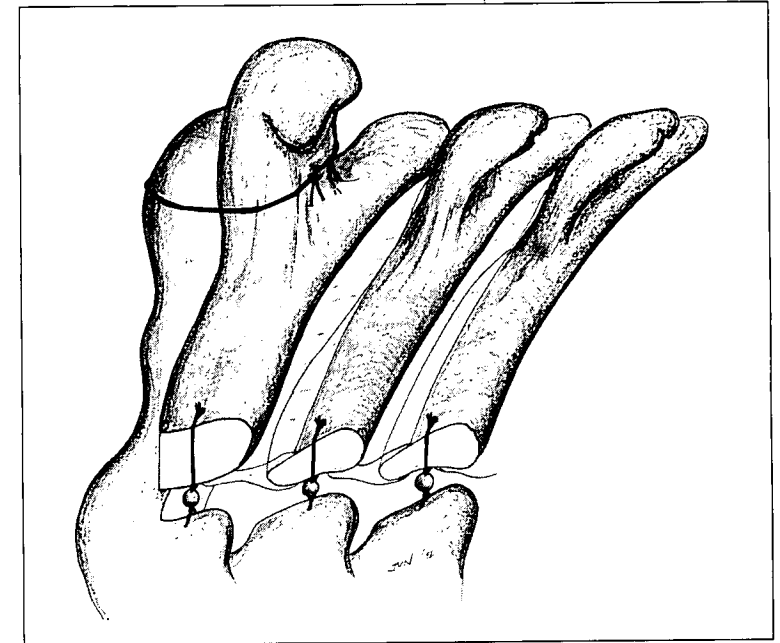

Fig. 2 Laminoplasty after transverse laminotomy using Koyama's method

$\mathrm{A}|\mathrm{B}| \mathrm{C}$
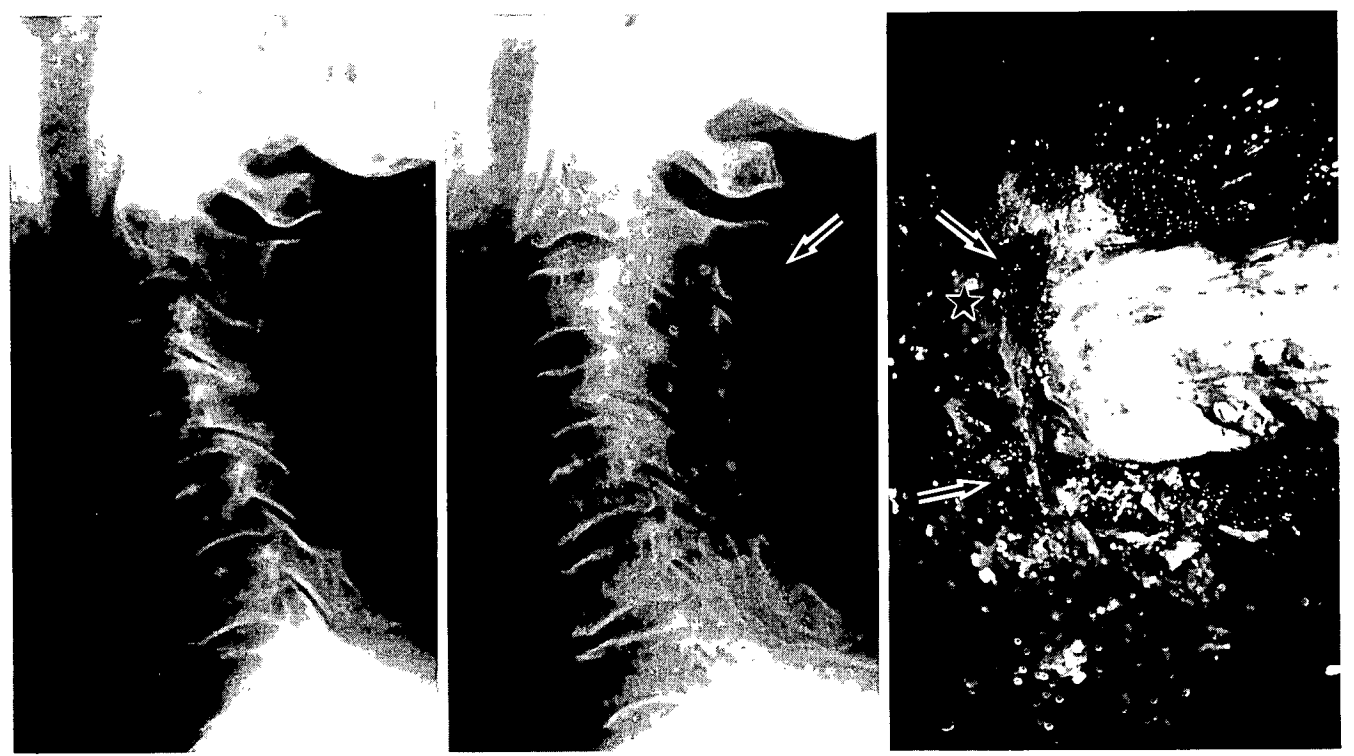

Fig. 3 A : Preoperative X-ray showed the anterior listhetic vertebrae.

$\mathrm{B}$ : Post-operative $\mathrm{X}$-ray showed the fusion of $\mathrm{C} 2$ transverse laminotomy.

$\mathrm{C}$ : Operative view of transverse laminotomy of $\mathrm{C} 2$ lamina (arrow) and spinous process (asterisk)

\section{方 法}

1985 年の小山ら 1$)$ の laminoplasty に準じて, 椎弓の両 側の縦切を drill で施行した後に, 連続して上端または下 端の椎弓の中央にまで laminotomy を加える. $1.5 \mathrm{~mm}$ 径の steel ball bar で椎弓, 棘突起を中央線で横切する. 黄色靱帯は頸椎弓の上縁では椎弓の上斜面と裏面の上 $1 / 3$ に，また下緑では椎弓裏面の下 $1 / 2$ に強く付着する ことによって軸椎以下の椎弓を機能的に連続性をもたせ ている。このために黄色䩚帯に損傷を与えることなく椎 弓を横切するには椎弓の上 $1 / 3 \sim 1 / 2$ の間で横切すれば
よいことになるが，実際の手術では $1.5 \mathrm{~mm}$ 径の bar を 使うこともあって，椎弓棘突起の中央上で横切する方が 棘突起も含めてうまく横切できる (Fig. 1). Reconstructionは横切した椎弓椎体間にもセラミックビーズを 使ってルーズに固定 (小山法) し, 浮遊した横切部の棘 突起を残した棘突起との間で浮いた分をずらした状態で 穴をあけ，チタンワイヤーまたは1-0ナイロン系を用い 強固に縫着する.その他の椎弓は小山法で形成する (Fig. 2). 術後の安静は術当日のみとし, 創部痛がないかぎり翌 日からカラー装着のみで歩行が可能である，6例に本法 を施行し良好な経過を得, 現在長期フォーローアップ中 である。 


\section{症 例}

代表的症例を呈示する。

患 者：69 歳, 女性, Y. M.

Developemental narrow spinal canal with anterior listhesis $\left(\mathrm{C}_{2-6}\right)$ の診断で modified Koyama's method (以下, 本法といい, また横切した椎弓レベルは Cn half という）を $\mathrm{C}_{2}$ half- $\mathrm{C}_{6}$ 間で施行した。術後の軸椎棘突 起の癒合も良好であり, anterior listhesis の悪化は認め なかった (Fig.3)。

\section{考 察}

われわれの過去 30 余例の小山法による laminoplasty の経験から切除された en bloc laminae の長さは, 垂直 方向の加重で約 10\%の伸びを示したが, それ以上の伸展 は通常の加重ではできなかった。黄色䩗帯は伸縮自在の ゴムバンド様の役目ばかりではなく, 頸椎前屈時の過後 弯をひいては swan neck deformity を防ぐ重要な支持 組織であると考えられる。この点における biomechanical な研究は椎体やfacetにおいて多く成されてい るが, 黄色䩚帯においては涉猙し得たかぎりではなく2), 黄色靯帯の伸縮性という特殊な機能の評価が困難なため と思われた. 椎弓後方支持組織としての特に軸椎を上端
としてこの方法で reconstructionすることは, anterior listhesis を伴う頸椎には有用であると考え，本法を施行 し listhetic vertebrae の悪化は認めず, 有効な方法であ ると思われた。また椎弓棘突起の骨瘾合は数力月で完了 するために，小山法におけるセラミックビーズを核とす る椎弓骨化が完了する約 1 年以内の後方支持組織の biomechanical な補強としても有用であると考えられる.

\section{結 語}

Transverse laminotomy は顕微鏡下でのみ安全に施 行される術式であり, 黄色勒帯の垂直方向の機能温存を 図れる方法である。また microneurosurgery を習得した 術者になら誰にでも春椎脊髄外科における必要最小限度 の術野を提供し得る術式である。

\section{文 献}

1) Koyama $T$, Handa $J$ : Cervical laminoplasty using apatite beads as implants. Experiences in 31 patients with compressive myelopathy due to developmental canal stenosis. Surg Neurol 24:663-667, 1985.

2) Krag $\mathrm{MH}:$ Biomechanics of the cervical spine. in Frymoyer JW (ed) : The adult spine. Principles and practice, New York, Raven Press, 1991 pp. 929-965.

3）小野村敏信, 林 浩一郎編: 靧椎外科の進歩, 東京, 南 江堂, 1982, pp. 227-262.

\section{椎弓横切術一Technical note- \\ 魏 秀復 高橋 淳金本幸秀 三國信啓 \\ 松林景子 岡本新一郎福光 太郎}

椎弓横切術 (transverse laminotomy) とは黄色靸帯の椎弓裏面の付着部位上 1/3 と下 1/2 の 間で椎引棘突起を顕微鏡下に $1.5 \mathrm{~mm}$ ball bar で drilling することによって, 黄色靱帯を損傷す ることなく椎引䊂突起を上下に2 分割することである. これに小山法による laminoplasty と横切 部の椎弓棘突起を再瘾合させることによつて, 従来の頸椎管拡大術では望めながつた重要な後方支持 組織としての黄色靱帯の機能温存が眓れる. 